\title{
Recent Advances on Preparation Method of Ti-Based Hydrogen Storage Alloy
}

\author{
Lina Liang, Feng Wang*, Maohua Rong, Zhongmin Wang, Songtao Yang, Jiang Wang*, \\ Huaiying Zhou
}

Guangxi Key Laboratory of Information Materials, School of Materials Science and Engineering, Guilin University of Electronic Technology, Guilin, China

Email: *wf@guet.edu.cn, ${ }^{\star}$ wangjiang158@163.com

How to cite this paper: Liang, L.N., Wang, F., Rong, M.H., Wang, Z.M., Yang, S.T., Wang, J. and Zhou, H.Y. (2020) Recent Advances on Preparation Method of Ti-Based Hydrogen Storage Alloy. Journal of Materials Science and Chemical Engineering, 8, 18-38.

https://doi.org/10.4236/msce.2020.812003

Received: November 6, 2020

Accepted: December 19, 2020

Published: December 22, 2020

Copyright $\odot 2020$ by author(s) and Scientific Research Publishing Inc. This work is licensed under the Creative Commons Attribution International License (CC BY 4.0).

http://creativecommons.org/licenses/by/4.0/

\section{(c) (i) Open Access}

\begin{abstract}
Ti-based hydrogen storage alloy is one of the most common solid-state hydrogen storage materials due to its high hydrogen absorption capacity, low dehydrogenation temperature and rich resources. This paper mainly presents the influence of several different preparation methods of Ti-based hydrogen storage alloys on the hydrogen storage performance including traditional preparation methods (smelting, rapid quenching and mechanical alloying) and novel methods by plastic deformation (cold rolling, equal channel angular pressing and high-pressure torsion). The microstructure analysis and hydrogen storage properties of Ti-based alloy are summarized thoroughly corresponding with the preparation processes mentioned above. It was found that slight introduction of lattice defects including dislocation, grain boundary, sub-grain boundary and cracks by severe plastic deformation (SPD) was beneficial to improve the hydriding/dehydriding kinetic characteristic. However, the nonuniform composition and residual stress of the alloy may be caused by SPD, which is not conducive to the improvement of hydrogen storage capacity. In the future, it would be expected that new methods and technologies combined with dopant and modification are applied to Ti-based hydrogen storage alloys to make breakthroughs in practical application.
\end{abstract}

\section{Keywords}

Ti-Based Alloy, Preparation Methods, Hydrogen Storage Performance, Severe Plastic Deformation, Lattice Defects

\section{Introduction}

Hydrogen energy is considered as a promising alternative energy in the future 
due to its low cost, high energy density, eco-friendly and renewable characteristics [1] [2] [3] [4]. Compared with gaseous and liquid hydrogen storage, solid hydrogen storage has the advantages of high hydrogen storage capacity, convenient transportation, high energy density and excellent security [5] [6]. A US Department of Energy (the US Doe) funded project in recent years intends to develop metal hydride compressors for high pressure ( $>875$ bar) hydrogen delivery to refuel fuel-cell-powered vehicles. In addition, many companies and institutions around the world are also involved in the development of metal hydride compressors including HYSTORE Technologies Ltd. (Cyprus), HySA Systems Centre of Competence, HYSTORSYS AS (Norway), South African Institute for Advanced Materials Chemistry, both hosted by the University of the Western Cape (South Africa) as well as SKTBE OAO (Russia) [7]. Studies have shown that metal hydride hydrogen storage and compression technology have been proved to be effective in small and medium-sized energy storage systems [8]. Therefore, the development trend of hydrogen energy in the future is bright and promising, but it still faces serious challenge on how to achieve safe and efficient storage of hydrogen energy. Currently, hydrogen storage systems are mainly divided into two types involving physical storage and materials-based storage (as shown in Figure 1). This paper focuses on Ti-based hydrogen storage alloys in materials-based storage system.

Hydrogen storage alloy is composed of two elements. The A site element has a strong affinity with hydrogen and is mainly distributed in IA-VB group metals, such as $\mathrm{Ti}, \mathrm{Zr}, \mathrm{Ca}, \mathrm{Mg}, \mathrm{V}, \mathrm{Nb}, \mathrm{Hf}, \mathrm{Re}$ (rare earth elements); the B site element is scarcely hydrogen absorption capacity, which controls the reversibility of absorption/dehydrogenation cycle and regulates enthalpy change and decomposition pressure, such as $\mathrm{Fe}, \mathrm{Co}, \mathrm{Ni}, \mathrm{Cr}, \mathrm{Cu}, \mathrm{Al}$, etc. At present, a variety of hydrogen storage alloys have been developed, according to the main elements of hydrogen storage alloy classification: rare earth series, magnesium series, titanium

(a)
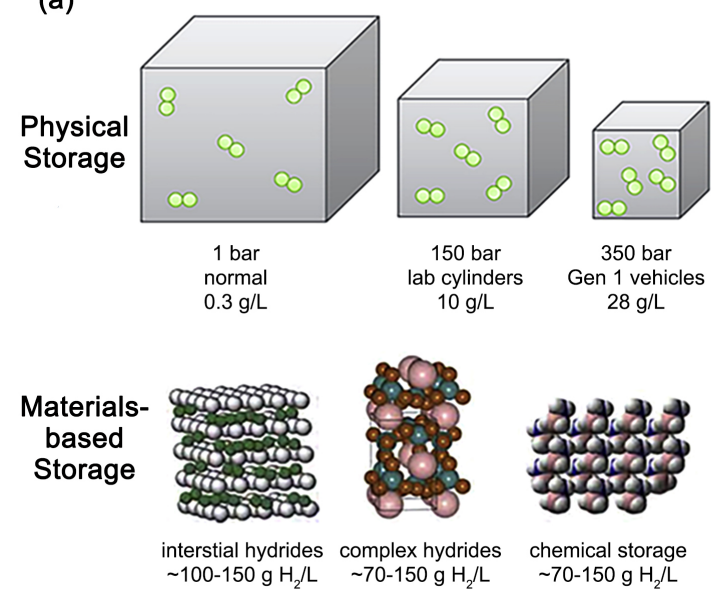
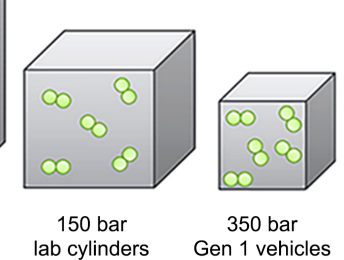
150 bar
lab cylinders $10 \mathrm{~g} / \mathrm{L}$

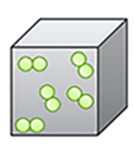
350 bar $28 \mathrm{~g} / \mathrm{L}$
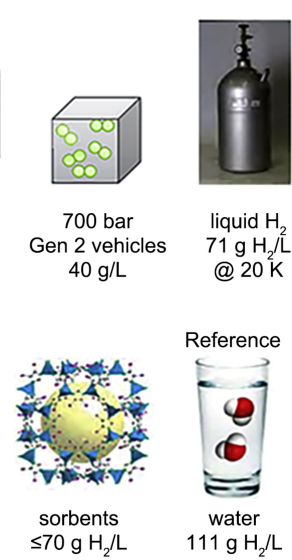

(b)

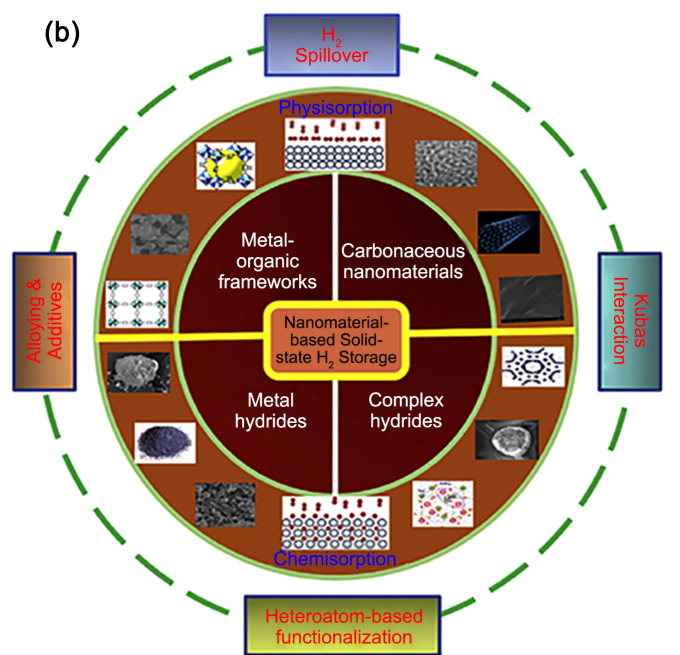

Figure 1. (a) Compressed hydrogen and materials-based hydrogen storage [10]. (b) Schematic representation including various nanomaterials as potential candidates for solid-state hydrogen storage, and some methods to enhance their storage capacity [9]. 
series, vanadium based solid solution and zirconium series, etc. In terms of the intermetallic compounds, hydrogen storage alloys are classified as $\mathrm{AB}_{5}\left(\mathrm{CaCu}_{5}\right.$ structure), $\mathrm{AB}_{2}$ (Laves phase) [11], $\mathrm{AB}$ ( $\mathrm{CsCl}$ structure) and $\mathrm{A}_{2} \mathrm{~B}\left(\mathrm{AlB}_{2}\right.$ structure) [5].

Ti-based alloys are widely used in the field of hydrogen storage. Except TiFe, all of them are $\mathrm{AB}_{2}$ type $(\mathrm{A}=\mathrm{Ti}, \mathrm{Zr}, \mathrm{B}=\mathrm{Cr}, \mathrm{Mn}, \mathrm{Ni}, \mathrm{V})$, which are likely to form $\mathrm{BCC}$ structure and $\mathrm{C} 14$ laves phase. Compared with $\mathrm{AB}_{5} / \mathrm{AB}_{2} / \mathrm{AB}$ alloy, Ti-based alloy has higher hydrogen storage capacity at room temperature. Compared with magnesium-based hydrogen storage alloys, Ti-based alloy has lower working temperature and enthalpy change value [12] [13]. It is commonly used as solid-state hydrogen storage, Ni-MH rechargeable battery as well as metal hydride compressor [14]. For a long time, Ti-based hydrogen storage alloys was prone to activation difficulty, surface poisoning, be poor kinetic characteristic and low dehydrogenation capacity at room temperature [15] [16]. In recent years, studies have shown that samples undergo mechanical deformation such as high-pressure torsion (HPT), forging, ball milling (BM) and cold rolling (CR), which can boost the first hydrogenation (activation) of metal hydrides by making defects and reducing the size of microcrystal to nanocrystalline [17] [18]. Furthermore, the electrochemical properties of the alloy can be enhanced by BM method coated with porous film. So far, some extensive attempts have been made on the preparation direction of Ti-based hydrogen storage alloy with following main approaches. Firstly, the comprehensive properties were investigated through the combination of element doping and preparation method. Secondly, organic catalytic materials were combined with the preparation technology to form a special structure so as to facilitate hydrogen absorption. Third, different preparation methods were compared and analyzed to obtain the best preparation scheme. This paper summarizes and analyzes the preparation methods in recent years to further understand the influence of the preparation methods on the hydrogen storage properties of the sample (kinetic performance, cyclic stability, hydrogen absorption/dehydrogenation capacity, etc.). It is expected to provide beneficial information to the researchers and promote the development of hydrogen storage alloys in the future.

\section{Preparation Methods}

\subsection{Smelting}

At present, the smelting methods are generally used in Ti-based hydrogen storage alloys involving arc smelting, induction melting and maglev melting, among which arc smelting under vacuum condition is a traditional method to prepare Ti-based alloys. Ti-Mn-V system alloy prepared by arc smelting, which was found that proper addition of vanadium increased hydrogen absorption and reduced platform pressure [19]. [3] and [20] fabricated Ti-V-Cr system alloys by vacuum arc melting combined with heat treatment, discovering that the kinetic properties of hydrogenation/dehydrogenation were significantly improved when 
the two preparation processes were combined. Compared with arc melting, induction smelting was mostly employed for the smelting of volatile elements (La, $\mathrm{Mg}, \mathrm{Y}, \mathrm{Ni}, \mathrm{Mn}$, etc.). [21] obtained high purity $\mathrm{Ti}_{45} \mathrm{Zr}_{38} \mathrm{Ni}_{17}$ alloy by induction smelting. [22] produced $\mathrm{Ti}-\mathrm{V}$ system alloy under vacuum condition using intermediate frequency induction furnace. However, its hydrogen absorption capacity was only $1.25 \%$ and hydrogen dehydrogenation capacity was $0.85 \%$, which was attributed to the chemical reaction between $\mathrm{Ti}-\mathrm{V}$ alloy and crucible during the preparation. Therefore, it is necessary to ensure that the fused alloy do not react with copper crucible under high temperature environment during smelting and consider that volatile elements may cause uneven chemical composition of the alloy. Levitation melting technology is suitable for active metals, refractory alloys, high-purity materials and highly contaminated samples. [23] prepared high-purity Ti-V based alloys by levitation smelting to explore the microscopic phase composition of the samples. Moreover, uniform and high-purity $\mathrm{Ti}_{8} \mathrm{Cr}_{12} \mathrm{~V}_{80}$ alloy was also gained by levitation smelting and the initial hydrogen storage capacity only decreased by $1.4 \%$ after 500 cycles, which exhibited excellent cycling stability [24]. Arc smelting is extremely conventional method to apply to Ti-based hydrogen storage alloys by comparing with the remaining two smelting methods, because it is more suitable for the requirements of practical application such as low cost, high efficiency as well as simple operation.

\subsection{Rapid Quenching}

Rapid quenching (RQ) as a rapid cooling way could obtain thin belt of uniform mass from amorphous to microcrystalline state, and then acquired nanocrystalline after heat treatment. Amorphous samples with high strength, high hardness and excellent corrosion resistance could be formed through RQ [21] [25] [26] and [27] made Ti-Zr-Ni icosahedral quasicrystals (I phase) with the rotational symmetric phase of icosahedral point group by RQ, which could provide more tetrahedral gap positions occupied with hydrogen atom to significantly improve the hydrogen storage capacity of Ti-based alloy [28] [29]. Meanwhile, I phase could be used as a negative material for NiMH batteries due to its high discharge capacity [30]. In addition, [31] adopted the segmented quenching process at $800^{\circ} \mathrm{C}-950^{\circ} \mathrm{C}$, which reduced the strain softening performance and caused the dynamic phase transition from $\beta$ phase to $\alpha$ phase. In the process of sample preparation, RQ is mainly used to improve grain size, grain boundary and phase composition [32]. Lattice defects provide more channels for hydrogen diffusion and optimize the kinetic performance of alloy. However, the brittleness of the material increases after RQ, resulting in the formation of deformation, cracks and oxidation. For hydrogen storage alloys, a few cracks are beneficial to hydrogen diffusion to improve the kinetic properties of hydrides, but it can reduce hydrogen storage capacity of the sample. Meanwhile, surface oxidation is not conducive to hydrogen penetration. Therefore, RQ should be used reasonably in the preparation process. 


\subsection{Mechanical Alloying}

Mechanical alloying (MA) is also known as the mechanical ball milling. Different ways of MA are shown in Figure 2. After MA treatment, the alloy particles realize the transformation from large size to nanometer level, which is accompanied with the generation of lattice defects involving lattice strain, dislocation density and cracks, etc. The scanning electron microscope (SEM) of TiFe alloy was shown in Figure 3. The SEM displayed clearly that TiFe grain size decreased with the increase of the milling time and the cracks of TiFe alloy appeared definitely in 6 hours. Furthermore, the influence of different BM conditions on hydrogen absorption capacity was summarized in Table 1. [34] mentioned that the formation of defects after MA treatment for Ti-Al-Si ternary alloy were caused by the slip system of $\mathrm{TiAl}_{3}$ (FCC) or $\mathrm{Ti}_{5} \mathrm{Si}_{3}$ (HCP) phase, which was essentially attributed to grain refinement and the generation of surrounding intermetallic compounds.

In the process of hydrogenation/dehydrogenation, it was definitely found that the appearance of a few cracks accelerated the rate of hydrogen absorption. [35] and [36] have reported that hydrogen diffusion channels increased with the enlargement of grain boundary ratio and hydrogen absorption kinetics was boosted

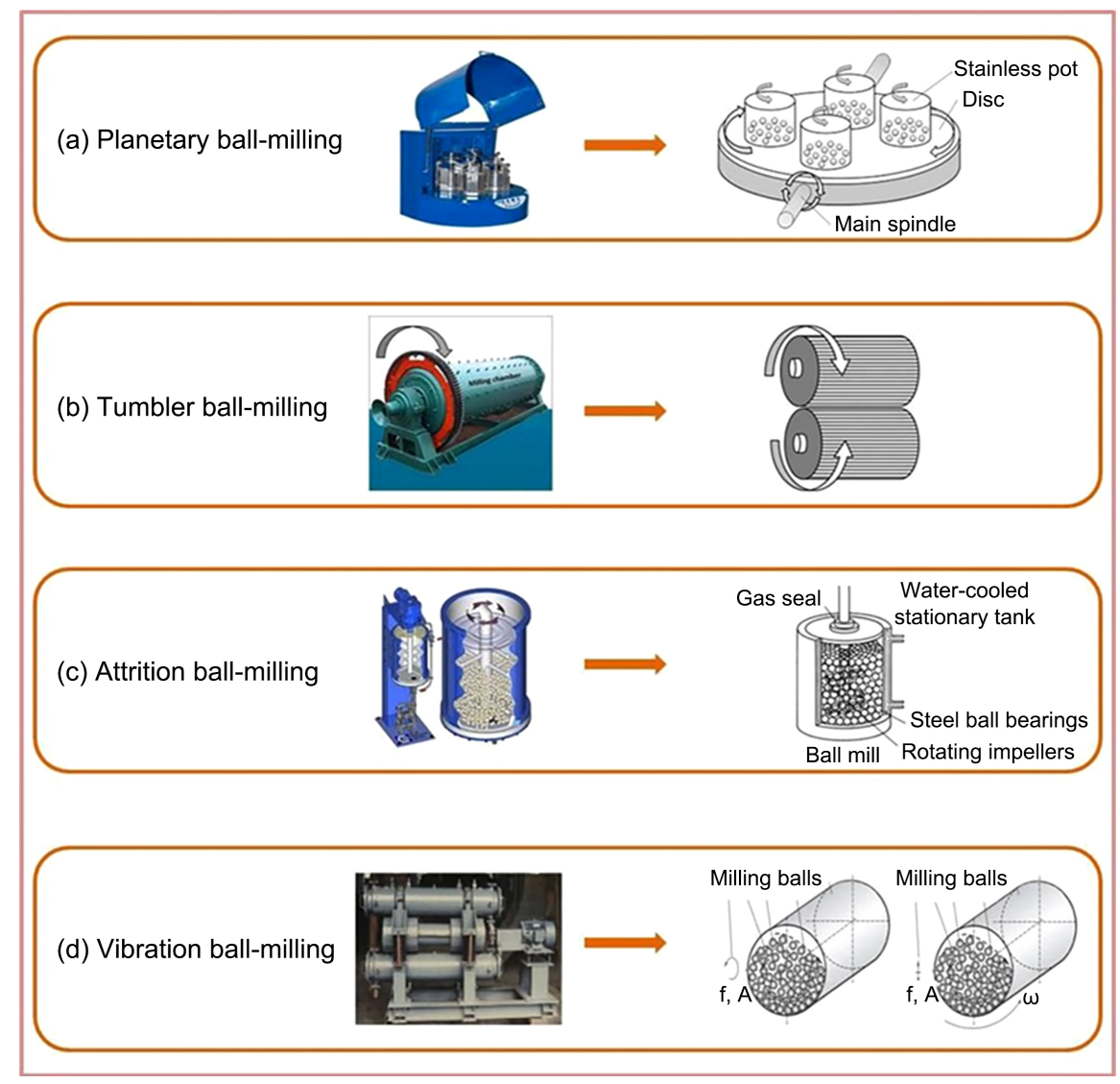

Figure 2. Different types of ball milling and its working principles: (a) Planetary ball milling, (b) Tumbler ball milling, (c) Attrition ball milling, and (d) Vibration ball milling (where $\mathrm{f}$ is vibration frequency, $\mathrm{A}$ is vibration amplitude, and $\omega$ is angular velocity) [33]. 

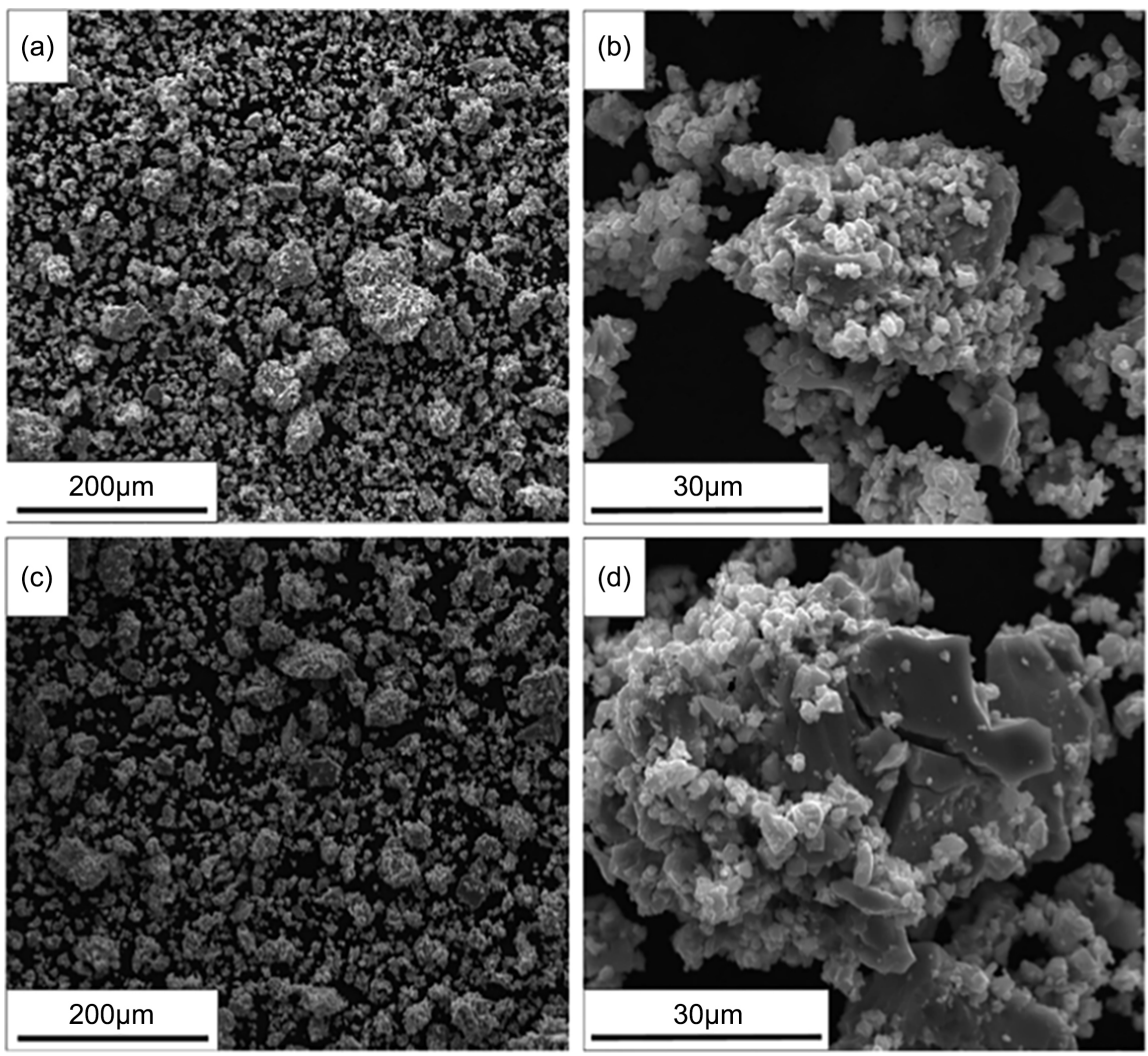

Figure 3. The SEM images of TiFe alloy by BM: (a), (b) for 2 h, (c), (d) for 6 h [37].

Table 1. The hydrogen absorption capacity under different ball milling conditions.

\begin{tabular}{|c|c|c|c|}
\hline Ball milling time $(\mathrm{h})$ & $\begin{array}{l}\text { Hydrogen absorption } \\
\text { conditions }\end{array}$ & $\begin{array}{l}\text { Hydrogen absorption } \\
\text { capacity (wt } \%)\end{array}$ & References \\
\hline 2 & $295 \mathrm{~K}, 400$ bar & 1.4 & [44] \\
\hline 10 & $295 \mathrm{~K}, 50 \mathrm{bar}$ & 1.09 & {$[45]$} \\
\hline 2 & $295 \mathrm{~K}, 40 \mathrm{bar}$ & 1.35 & {$[44]$} \\
\hline 2 & $295 \mathrm{~K}, 20$ bar & $\sim 1.0$ & [44] \\
\hline 2 & $308 \mathrm{~K}, 60$ bar & $\sim 1.0$ & {$[46]$} \\
\hline 20 & $298 \mathrm{~K}, 250$ bar & 1.3 & {$[47]$} \\
\hline 36 & $303 \mathrm{~K}, \sim 80 \mathrm{bar}$ & 1.5 & {$[18][18]$} \\
\hline 38 & $\mathrm{RT}^{\mathrm{a}}, \sim 27 \mathrm{bar}$ & $\sim 1.1$ & {$[48]$} \\
\hline 40 & $\mathrm{RT}, \sim 19 \mathrm{bar}$ & 0.94 & [49] \\
\hline 90 & $298 \mathrm{~K}, 50$ bar & $\sim 1.3$ & {$[50]$} \\
\hline 2 & RT, 20 bar & 0.9 & {$[37]$} \\
\hline 6 & RT, 20 bar & 1.0 & [37] \\
\hline
\end{tabular}

${ }^{\mathrm{a}}$ Room temperature. 
in the wake of the diminution of grain size after BM. However, it is a fact that grain boundary without absorbing hydrogen atom is only used as hydrogen diffusion channel. Thus, the increase of grain boundary proportion has a negative impact on hydrogen storage capacity of Ti-based alloy. At present, it can be achieved the purpose of hydrogen fixation by doping elements with strong hydrophilic ability $(\mathrm{V}, \mathrm{Fe})$ further to overcome the shortcoming of low hydrogen storage capacity. [38] fabricated I phase by combining MA with annealing process. However, the second discharge cycle capacity (130 mAh/g) of $\mathrm{Ti}_{49} \mathrm{Zr}_{26} \mathrm{Ni}_{25-\mathrm{x}} \mathrm{Pd}(\mathrm{X}$ = 3.6) alloy was significantly lower than the first discharge capacity $(220 \mathrm{mAh} / \mathrm{g})$ with the increase of Pd content, which was inconsistent with the laboratorial finding of [27]. Therefore, it was inferred that the discharge performance of Ti-Zr-Ni-Pd system alloy after RQ was better than that of MA method, which could be on account of the more stable I phase formed by RQ. The maximum discharge capacity of Ti-based alloy under different preparation methods were shown in Table 2. It was discovered that $\mathrm{Ti}_{49} \mathrm{Zr}_{26} \mathrm{Ni}_{22} \mathrm{Pd}_{3}$ alloy combined MA with annealing process could achieve the maximum discharge capacity of 220 $\mathrm{mAh} / \mathrm{g}$. MA is not only used to refine internal grain size and also applied to surface coating of Ti-based hydrogen storage alloy. As is known, Ti-based alloy tends to be contaminated by impurity gas. It is facile to lose the activity of hydrogenation/dehydrogenation when the activated alloy comes into contact with impurity gases such as $\mathrm{O}_{2}, \mathrm{CO}_{2}$ and $\mathrm{H}_{2} \mathrm{O}$ in the air. Studies have shown that they may form metal oxides, hydroxides, carbohydrates and water if gaseous impurities interact with the alloy surface, which hinder the dissociation of hydrogen molecules and the penetration of hydrogen atoms, thus significantly reducing the hydrogen absorption rate [39] [40] [41]. The surface coating of Ti-based hydrogen storage alloy via $\mathrm{BM}$ is favored by researchers. Liu et al. coated porous polyaniline (P-PANI) on the surface of $\mathrm{Ti}_{49} \mathrm{Zr}_{26} \mathrm{Ni}_{25}$ alloy by BM to form a composite material [42]. As shown in Figure 4. P-PAN formed a unique sea urchin-like morphology and porous structure on the surface of the composite material. The perfect pore structure increased the specific surface area of sample, accelerating the electron transfer between the alloy and electrolyte during charging/discharging. Meanwhile, the increase of specific surface area promoted the diffusion of hydrogen atoms and enhanced the corrosion resistance of hydrogen storage alloy, which improved the electrochemical activity and reaction kinetics of the electrode [43]. Liu et al. had also obtained the porous $\alpha-\mathrm{Fe}_{2} \mathrm{O}_{3}$ coated $\mathrm{Ti}_{49} \mathrm{Zr}_{26} \mathrm{Ni}_{25}$ alloy with unique surface texture by BM method, and found that the discharge capacity of the composite material with $5 \% \alpha-\mathrm{Fe}_{2} \mathrm{O}_{3}$ reached $259.6 \mathrm{mAh} / \mathrm{g}$, which was better than the discharge capacity of pure alloy [30]. MA had a wide range of application among the material processing. In the study of magnesium-based hydrogen storage materials, programmable logic controller (PLC) control technology was combined with MA technology, which not only increased the purity of the alloy also improved the maximum discharge capacity as well as capacity retention rate. 
Table 2. The maximum discharge capacity of Ti-based alloy by different preparation methods.

\begin{tabular}{cccc}
\hline Preparation & Sample & $\begin{array}{c}\text { Maximum discharge capacity } \\
\text { Cmax }(\mathrm{mAh} / \mathrm{g})\end{array}$ & References \\
\hline $\mathrm{Ti}_{45} \mathrm{Zr}_{35} \mathrm{Ni}_{20}$ & 79 & \\
$\mathrm{Ti}_{45} \mathrm{Zr}_{35} \mathrm{Ni}_{19} \mathrm{Pd}$ & 105 & \\
& $\mathrm{Ti}_{45} \mathrm{Zr}_{35} \mathrm{Ni}_{17} \mathrm{Pd}_{3}$ & 122 & \\
& $\mathrm{Ti}_{45} \mathrm{Zr}_{35} \mathrm{Ni}_{15} \mathrm{Pd}_{5}$ & 130 & \\
& $\mathrm{Ti}_{45} \mathrm{Zr}_{35} \mathrm{Ni}_{13} \mathrm{Pd}_{7}$ & 148 & \\
\hline MS + MA & $\mathrm{Ti}_{45} \mathrm{Zr}_{38} \mathrm{Ni}_{17}$ & 30 & \\
& $\mathrm{Ti}_{45} \mathrm{Zr}_{30} \mathrm{Ni}_{25}$ & 86 & \\
\hline MA + Anneal & $\mathrm{Ti}_{49} \mathrm{Zr}_{26} \mathrm{Ni}_{25}$ & 130 & \\
& $\mathrm{Ti}_{49} \mathrm{Zr}_{26} \mathrm{Ni}_{22} \mathrm{Pd}_{3}$ & 220 & \\
\hline
\end{tabular}

${ }^{\mathrm{a}}$ Melt-spinning, ${ }^{\mathrm{b}}$ Mechanical alloying.
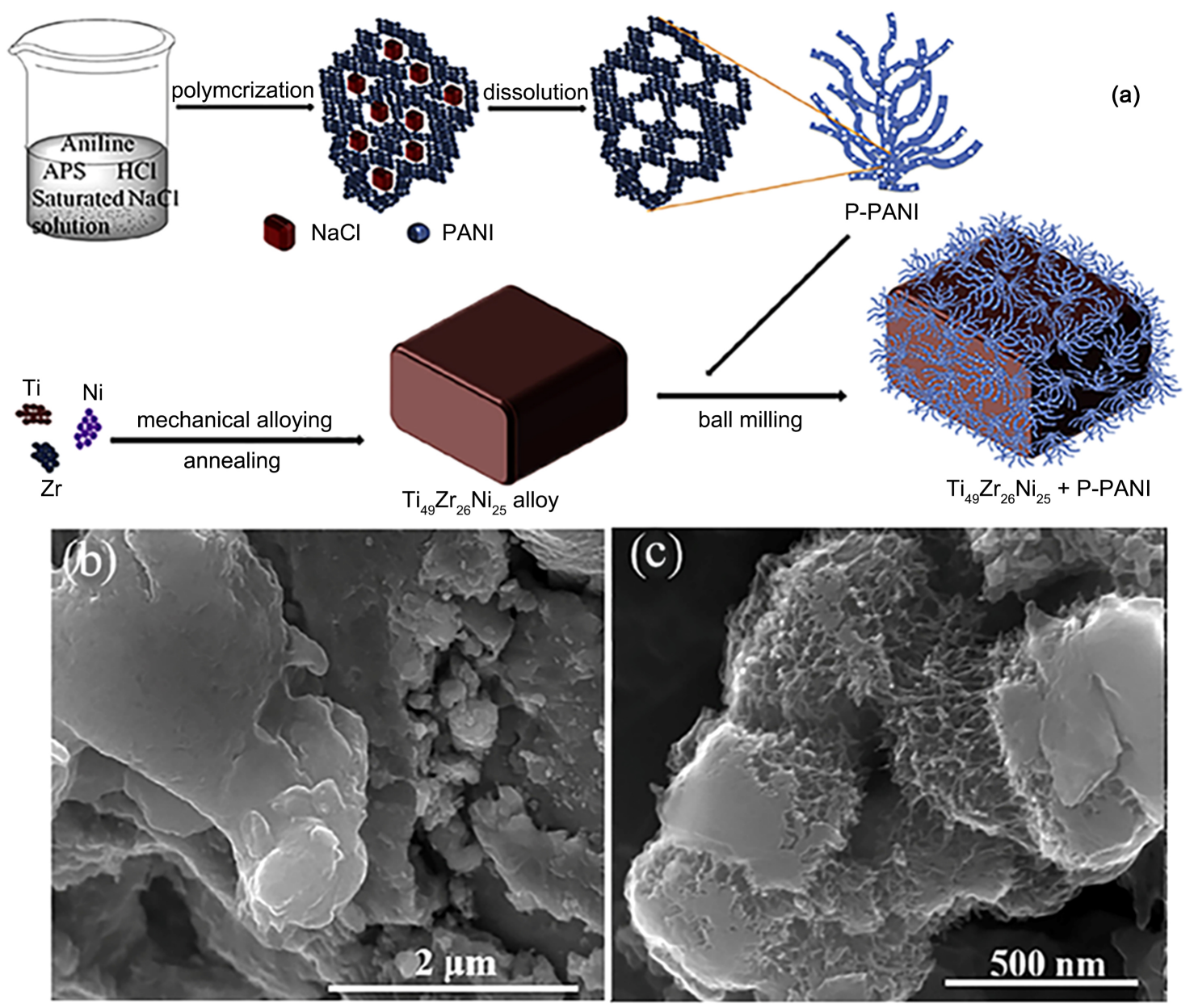

Figure 4. SEM images of the alloys: (a) Schematic diagram for the fabrication of $\mathrm{Ti}_{49} \mathrm{Zr}_{26} \mathrm{Ni}_{25}+\mathrm{P}-\mathrm{PANI}$, (b) $\mathrm{Ti}_{49} \mathrm{Zr}_{26} \mathrm{Ni}_{25}$, (c) $\mathrm{Ti}_{49} \mathrm{Zr}_{26} \mathrm{Ni}_{25}+$ Coated 3\% P-PANI by BM [42]. 


\subsection{Cold Rolling}

Cold rolling (CR) was utilized as a kind of cold plastic deformation whose grains were elongated along the deformation direction and properties tended to be anisotropic after CR. The cold-rolled samples generated smaller grain and more cracks with the number of CR increasing, which was shown in Figure 5. The occurrence of cracks resulted in the reduction of tetrahedral and octahedral positions that led to decreasing the hydrogen storage capacity of sample. [51] have adopted a roller with a diameter of $6.4 \mathrm{~cm}$ and a length of $8 \mathrm{~cm}$ to obtain a long and thin strip of Ti-Fe samples by CR (The crystal structure Ti-Fe samples is shown in Figure 6). [52] has minished the cross-sectional area of groove rolling samples from $5.8 \times 5.8 \mathrm{~mm}^{2}$ to $4.4 \times 4.4 \mathrm{~mm}^{2}$ to produce sub-grains with high density dislocation and cracks. It was found that the cold-rolled Ti-Fe samples had better hydrogen absorption capacity than those after mechanical ball milling. Generally, the average grain size after CR was $100 \mu \mathrm{m}-300 \mu \mathrm{m}$, while the average grain after BM was $100 \mathrm{~nm}-100 \mu \mathrm{m}$ [53]. The hydrogen absorption rate was not only related to the platform pressure also involved to the grain size [54]. Therefore, the kinetics of the sample after BM was slightly faster than that of CR, while its hydrogen storage capacity was slightly lower than that of CR samples, which was consistent with the conclusions of [17] and [35]. Research showed that the incubation period of hydrogenation reaction effectively reduced when the number of rolling increased from 5, 12 to 25 turns [17]. It has also been reported that the kinetics of $\beta \mathrm{Ti}-40 \mathrm{Nb}$ alloy increased with cold-rolling turns
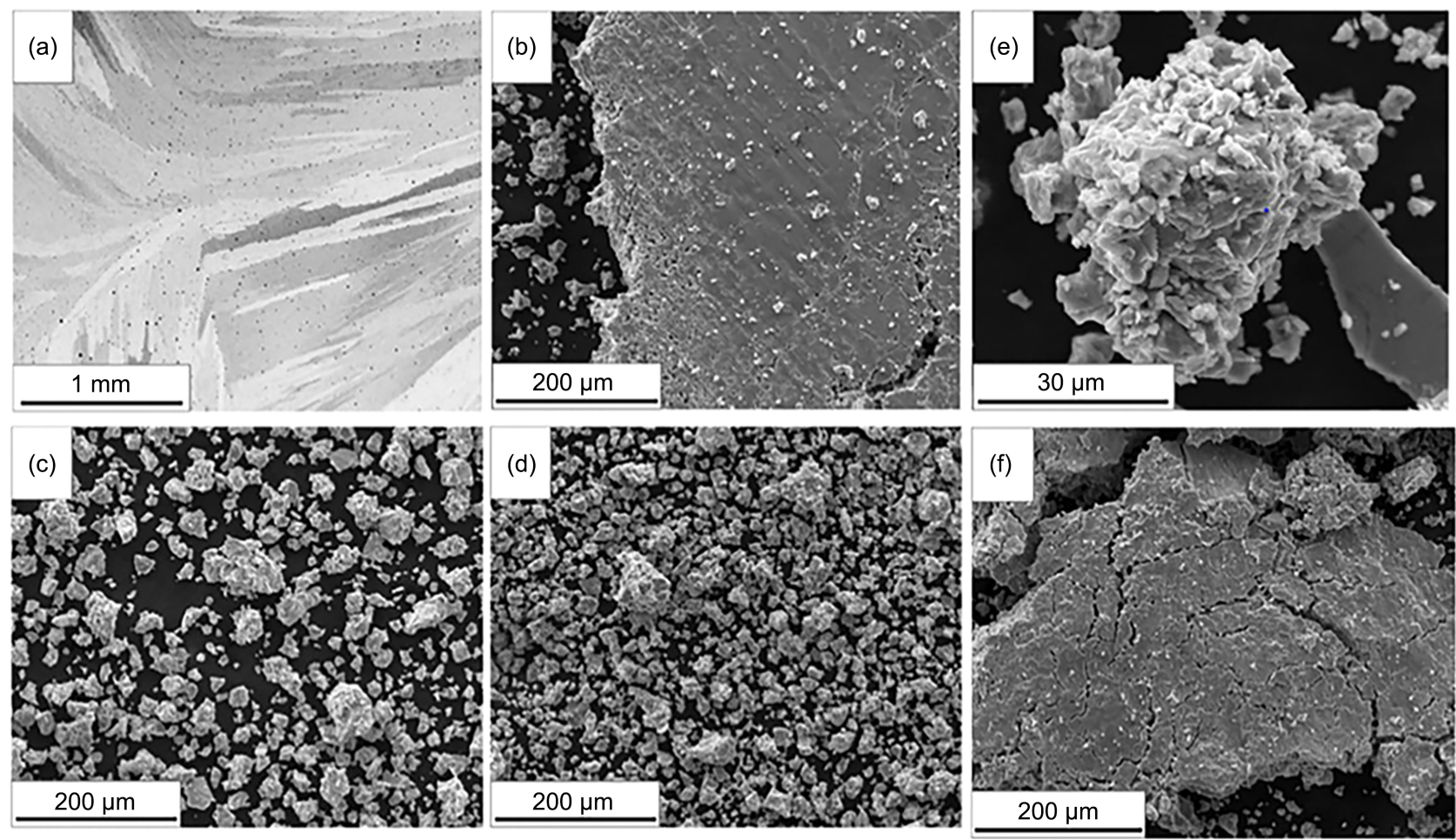

Figure 5. SEM diagram of TiFe sample: (a) Backscatter electron diagram of as-cast sample, (b) (c) secondary electron diagram of cold rolled for 20 times, (d) (e) (f) secondary electron diagram of cold rolled for 40 times [51]. 


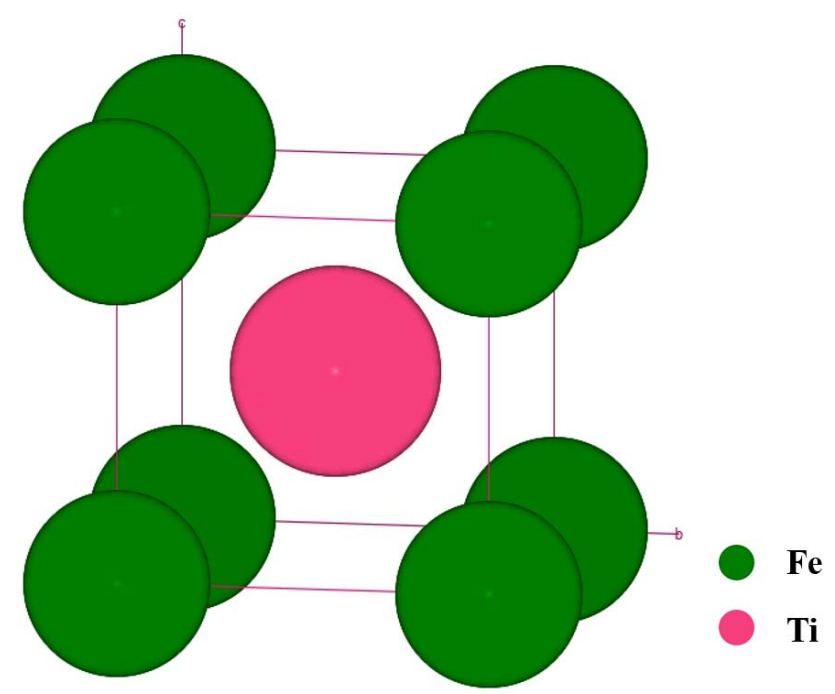

Figure 6. The crystal structure Ti-Fe samples.

increasing. At room temperature, samples deformed with 80 cycles absorbed $\sim 2.0 \mathrm{wt} \%$ of $\mathrm{H}_{2}$ after $15 \mathrm{~min}$, while samples deformed with 40 cycles absorbed $\sim 1.8 \mathrm{wt} \%$ during $2 \mathrm{~h}$. The cold-rolled samples showed excellent hydriding result compared with undeformed samples hydrogenated at $300^{\circ} \mathrm{C}$ that acquired a capacity of $\sim 1.7 \mathrm{wt} \%$ after $2 \mathrm{~h}$ (as shown in Figure 7) [55]. Therefore, it is proved that the increase of rolling cycles is capable of improving the hydrogen absorption capacity of Ti-based alloy. The fine powder particles can promote the hydrogen absorption ability after BM, while its anti-oxidation ability is not as strong as that of the cold-rolled thin strip.

As mentioned before, the CR process plays a significant role in the activation performance and hydrogen storage capacity for Ti-based hydrogen storage alloy. However, there is still residual stress in local position of sample during cold rolling, which causes crack, deformation, impact strength, bending strength, tensile strength, torsional strength as well as other shortcomings. Generally, the slight defects are conducive to activate alloy, but the presence of residual stress can stimulate the formation of amorphous structure to affect hydrogen absorption kinetics. Conventional heat treatment methods or vibration aging treatment can be adopted to eliminate the residual stress.

\subsection{Equal Channel Angular Pressing}

Equal channel angular pressing (ECAP) process was a shear deformation process in which polycrystalline samples were pressed into a specially designed mold to achieve a large amount of deformation. It was mainly through near-pure shear action during the deformation process to achieve grain refinement, thus significantly reinforcing the mechanical and physical properties of the material [56]. The schematic diagram of ECAP was shown in Figure 8. The principle of ECAP was substantially that the metal sample underwent deformation without changing the cross-sectional area and cross-sectional shape of the sample. 


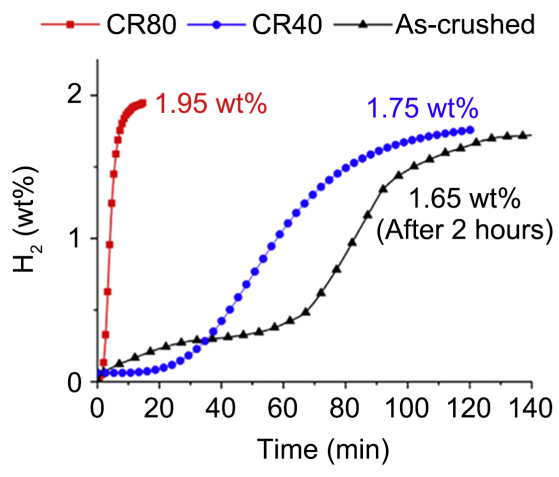

(a)

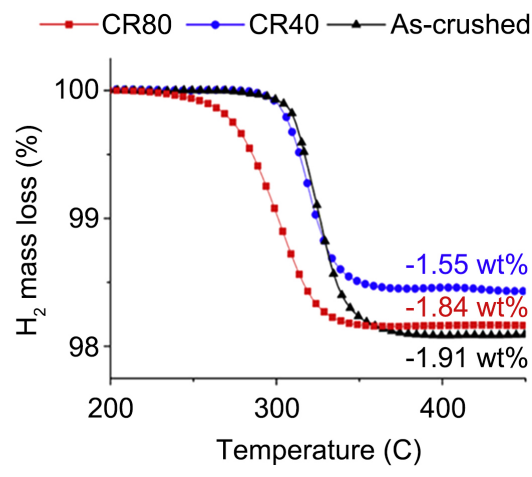

(b)

Figure 7. (a) Hydrogen absorption kinetics curve of $\mathrm{Ti}-40 \mathrm{Nb}$ alloy at $300^{\circ} \mathrm{C}$, (b) TGA desorption curves of $\mathrm{Ti}-40 \mathrm{Nb}$ alloy hydrogenated samples [55].
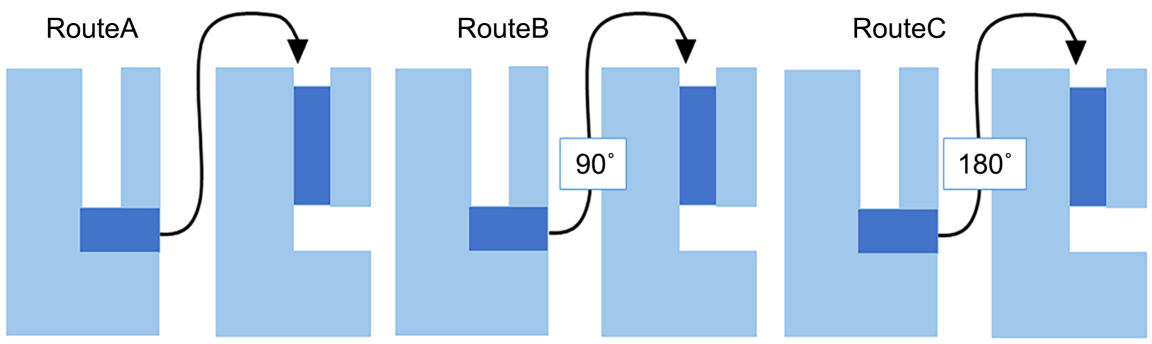

Figure 8. Schematic diagram of equal channel angular extrusion [56].

ECAP was a kind of effective severe plastic deformation (SPD) technique for producing ultrafine crystalline materials. Studies have shown that the average grain size of the ultrafine alloy prepared by ECAP was close to $330 \mathrm{~nm}$ and the alloy synthetical performance was higher than that of hot-rolled [57]. ECAP is now widely used in Mg-based hydrogen storage materials, while in Ti-based materials it is mostly applied to the preparation of materials for aerospace, biological and medical devices, etc. There are few reports in the application of Ti-based hydrogen storage alloys about ECAP. [58] reported that Mg-based alloys obtained fine grains and reached the maximum hydrogenation/dehydrogenation rate after 8 times of ECAP treatment and the maximum hydrogen storage capacity reached $6.2 \mathrm{wt} \%$. Meanwhile, the hydrogen absorption rate of the alloy was accelerated with the increase of $\mathrm{Mg}_{17} \mathrm{Al}_{12}$ phase in AZ61 magnesium alloy. It was indicated that ECAP technology efficaciously improved the hydrogen storage behavior of the alloy and promoted the formation of hydrogenabsorbing phase. [59] reported the phase transition of Ti-15Mo alloy treated via ECAP, and found that the hardness of the material increased from metastable $\beta$ phase to $\omega$ phase, but no further explanation was given on its hydrogen storage property. Additionally, [60] found that transient hydrogenation did not improve ductility and low cycle fatigue life of CP titanium over the levels achievable by straight ECAP. As mentioned before, it was confirmed that ECAP could stimulate hydrogen storage property of hydrogen storage alloys. Therefore, the application of ECAP process in Ti-based hydrogen storage alloys should be further explored. 


\subsection{High Pressure Torsion}

High-pressure torsion (HPT) was also a type of SPD process in which a torque was applied to the cross section while axial compression occurred. The frictional resistance could be changed into frictional force to achieve the dual effects of torsional deformation and simple compression deformation. The grain size of the sample could reach the nanometer level and the strength was abnormally high after HPT treatment [61] [62]. A schematic diagram of the boundary conditions of the disk sample during HPT processing was shown in Figure 9. Constraint conditions were set in order to strictly limit the sample geometry size and the friction force on the sample surface, so that the sample geometry shape did not change during HPT.

In the initial stage of HPT, dislocation accumulation and low angle sub-grain boundary was formed, which was gradually transformed into high angle grain boundary and nanocrystalline ( $\mathrm{NC}<100 \mathrm{~nm}$ ) with the increase of stress. Research showed that grain size decreased from $67 \mu \mathrm{m}$ to $53 \mathrm{~nm}$ after 10 cycles of HPT process and micro hardness value increased to the saturation value of 600 Hv when effective strain value reached 20 [63]. At the same time, it was indicated that that local dislocation could accelerate the phase transition with the increase of the number of HPT [64]. For Ti-based hydrogen storage, the occurrence of laves phase was beneficial to improve hydrogen absorption and electrochemical performance. $\mathrm{Ti}_{29.7} \mathrm{Ni}_{50.3} \mathrm{Hf}_{20}$ alloy was synthesized via HPT under the pressure of $6.0 \mathrm{Gpa}$ by [65], generating the mixture of amorphous phase and remaining nanocrystalline and causing the alternate belt of amorphous phase as well as nanocrystalline with high dislocation density by three rotations. Grain sizes of Ti-Al-Nb alloys prepared by different preparation methods was shown in Table 3. It was confirmed that HPT could increase the dislocation density and obtain ultrafine nanometer grains $(100 \mathrm{~nm}<$ UFG $<1000 \mathrm{~nm})$, which was favorable for enhancing the activation behavior of the alloy. Unfortunately, it was inclined to cause the uneven composition of samples after HPT, so the subsequent heat treatment process should be taken for composition homogeneousness.

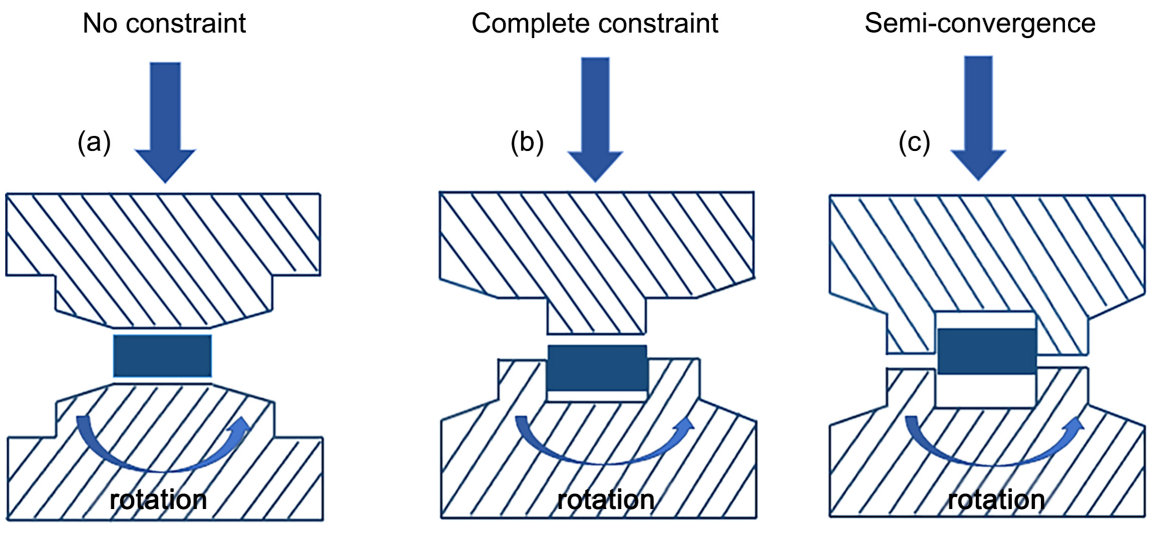

Figure 9. Schematic diagram of boundary conditions of disk samples during HPT processing (a) no constraint, (b) complete constraint, and (c) semi-convergence [61]. 
[52] studied the influence of HPT and groove rolling on TiFe alloy. It was pointed out that the hydrogen absorption capacity of sample was approximately 1.7 - $2 \mathrm{wt} \%$ in all hydrogenation cycle after HPT process, while the hydrogen absorption was $0.3-1.7 \mathrm{wt} \%$ in the first four cycles of groove rolling. It's indicated that the hydrogen absorption ability is better after HPT, which may be attributed to grain refinement and the generation of defects (as shown in Figure 10). Compared with heat treatment, it was demonstrated that TiFe samples treated with HPT were less likely to be oxidized when the sample exposed to air for a long time. Moreover, [65] has also mentioned that HPT was more effective for microstructure refinement compared with ECAP.

In recent years, HPT is increasingly used in Ti-based hydrogen storage alloys. It is mostly reported that the influence of microstructure and mechanical properties, while is rarely introduced on the kinetic and thermodynamic properties of the Ti-based alloys treated by HPT. In fact, HPT as an effective preparation technique can facilitate kinetic characteristics of hydrogen storage and is more applied to small bulk materials.

Table 3. Grain sizes of TiAlNb based alloys prepared by different preparation methods.

\begin{tabular}{cccc}
\hline Materials & Preparation & Grain size & References \\
\hline Ti-22Al-25Nb & $\mathrm{HP}^{\mathrm{a}}$ & $\sim 167 \mu \mathrm{m}$ & {$[66]$} \\
Ti-22Al-25Nb & $\mathrm{SPS}^{\mathrm{b}}+\mathrm{HT}^{\mathrm{c}}$ & $\sim 80 \mu \mathrm{m}$ & {$[67]$} \\
Ti-22Al-24Nb-0.5Mo & $\mathrm{HIP}^{\mathrm{d}}+\mathrm{RR}^{\mathrm{e}}$ & $\sim 30 \mu \mathrm{m}$ & {$[68]$} \\
Ti-22Al-25Nb & $\mathrm{MA}+\mathrm{SPS}$ & $\sim 6.2 \mu \mathrm{m}$ & {$[69]$} \\
Ti-20.3Al-22.1Nb-1.2Zr-1.3V-0.9Mo-0.3Si & $\mathrm{MIF}$ & $\sim 300 \mathrm{~nm}$ & {$[70]$} \\
Ti-22Al-25Nb & $\mathrm{HP}+\mathrm{HPT}$ & $\sim 53 \mathrm{~nm}$ & {$[63]$} \\
\hline
\end{tabular}

${ }^{a}$ Hot pressing, ${ }^{b}$ Spark plasma sintering, ${ }^{c} \mathrm{Heat}$ treating, ${ }^{\mathrm{d}} \mathrm{Hot}$ isostatic pressure, ${ }^{\mathrm{e}} \mathrm{Ring}$ rolling, ${ }^{\mathrm{f}} \mathrm{Multistep}$ isothermal forging.

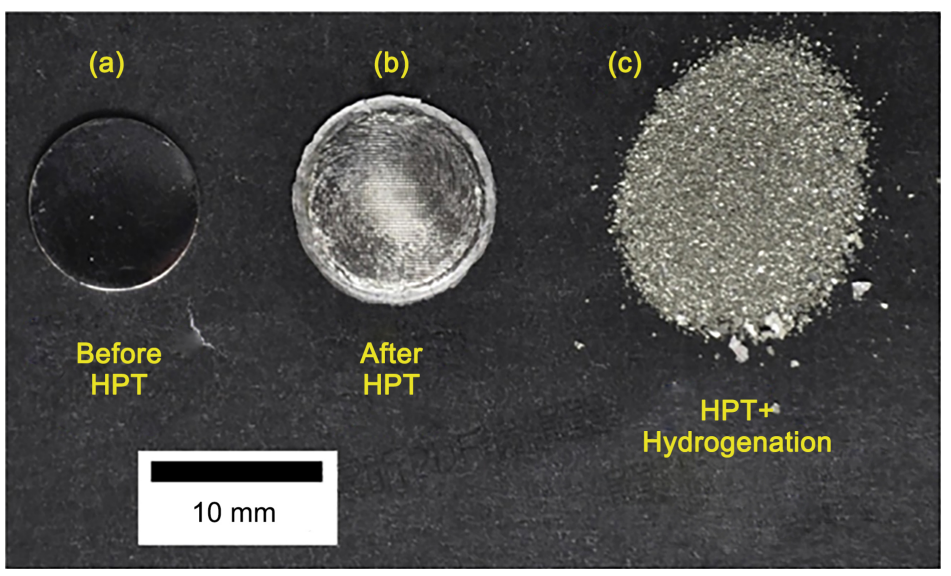

Figure 10. (a) Appearance of TiFe samples before HPT, (b) after HPT for 10 turns, (c) after HPT and 4 hydrogenation cycles [52]. 


\subsection{Other Methods}

(FeV80) ${ }_{48} \mathrm{Ti}_{26+\mathrm{x}} \mathrm{Cr}_{26}(\mathrm{x}=0$ - 4) alloy was synthesized via hydride powder sintering (HPS) method, which obtained the lower hydrogen adsorption/desorption ability compared with traditional induction melting [71]. The hydrogen absorption/dehydrogenation capacity were $2.8 \mathrm{wt} \% / 1.5 \mathrm{wt} \%(\mathrm{x}=0)$ and $3.3 \mathrm{wt} \% / 2.0$ $\mathrm{wt} \%(\mathrm{x}=4)$. However, the hydrogen absorption and dehydrogenation capacity at $\mathrm{x}=4$ was consistent with the smelting method, which was mainly attributed to Ti-rich oxide phase formed during HPS. The appearance of Ti-rich oxide phase reduced the content of $\mathrm{Ti}$ in the $\mathrm{BCC}$ phase, thus further affecting the reduction of lattice constant and hydrogen position [72].

\section{Applications}

Up to now, hydrogen energy as a renewable energy resource has been studied for nearly 60 years [73]. It has always been the goal of researchers to apply hydrogen storage alloys from laboratory to practical applications. Compared with magnesium-based alloy and rare earth series alloy, Ti-based alloy is more comprehensive, economical and safe in practical application. At present, some institutions and enterprises are developing and researching a complete power generation system by combining solid state hydrogen storage with fuel cell, desiring to realize the commercialization of hydrogen energy industry. At the same time, solid-state hydrogen storage alloys synthesized with the above preparation methods are now mostly used as the negative electrode materials for secondary batteries [43]. Meanwhile, hydrogen storage alloy not only is applied to provide hydrogen sources for small electric vehicle, bicycles and pony batteries, also utilized to micro-fuel cells [74] [75] and hydride compressors [8] (as shown in Figure 11). Now, the international hydrogen energy industry is facing a crucial problem that a safe and effective hydrogen storage system is still not found to satisfy large-scale practical applications for human being due to high cost and technical constraints.

\section{Summary and Outlook}

Currently, the major challenge for large-scale application of hydrogen storage systems is on how to achieve the requirements of safe and efficient hydrogen storage and supply. Ti-based hydrogen storage alloy as a promising candidate in the future has a very bright future and broad market in the field of batteries, energy vehicles, military industry, blasting materials and so on. In this paper, different preparation methods are summarized to provide guidance for obtaining Ti-based hydrogen storage alloys with excellent properties. From the above several preparation methods, melting and BM can promote the uniformity of the internal composition and contribute to the industrialization of Ti-based alloy. Meanwhile, the plastic deformation (CR, ECAP, HPT), BM and RQ play a momentous role in grain refinement and the introduction of microstructure defects. It is concluded that the uniform structure, refined grain, slight cracks and the 


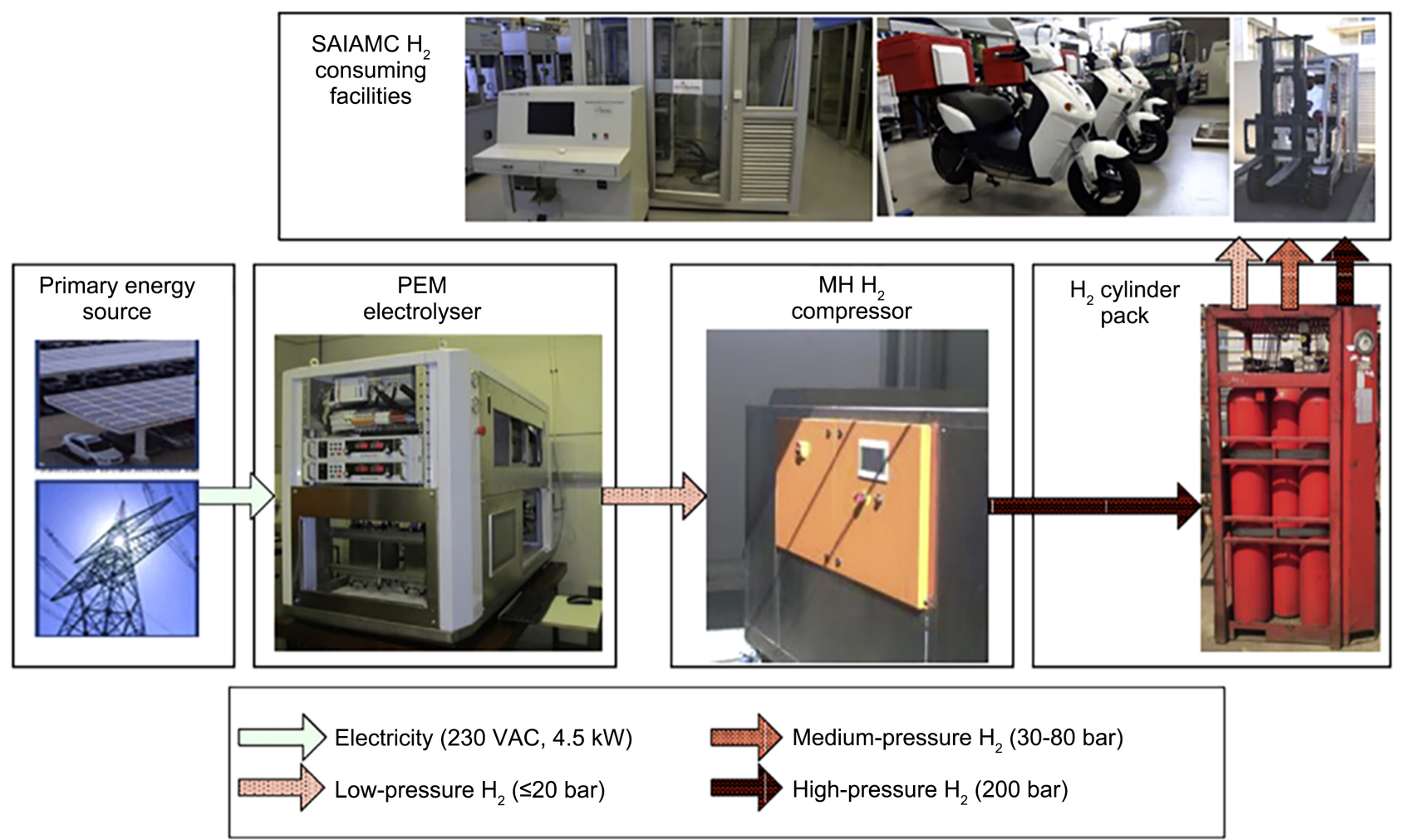

Figure 11. Schematic representation of hydrogen production, storage and distribution system at HySA Systems/South African Institute for Advanced Materials Chemistry (SAIAMC) research facility [8].

generation of hydrogen absorption phase are indeed conducive to the improvement of hydrogen storage performance involving kinetic characteristic and absorption/dehydrogenation capacity. However, the development of Ti-based hydrogen storage alloy from qualitative to quantitative change needs further exploration, because it is difficult to obtain alloys with outstanding comprehensive hydrogen storage performance simply by improving the preparation method. It is expected to acquire the ideal sample by the combination of preparation method with composition optimization and surface modification. At the same time, new methods and technologies are desired to be applied to Ti-based hydrogen storage alloys to make new breakthroughs.

\section{Acknowledgements}

This work was supported financially by the National Natural Science Foundation of China (Nos. 51961010, 51901054), the Natural Science Foundations of Guangxi Province (2019GXNSFBA245055), Guangxi Key Laboratory of Information Materials \& Guilin University of Electronic Technology, China (191016Z, 191018Z, 171001Z).

\section{Conflict of Interest}

We declare there is no conflict of interest and the sponsors had no role in the design, execution, interpretation, or writing of the study. Meanwhile, this work 
described in our paper has not been published previous and it is not under consideration for publication elsewhere. The manuscript for publication is approved by all authors and explicitly by the responsible authorities where the work was carried out. If accepted, the manuscript will not be published elsewhere in the same form, in English or in any other language, without the written consent of the Publisher. Thank you very much for your attention and consideration.

\section{References}

[1] Wang, F., Li, R., Ding, C., Tang, W., Wang, Y., Xu, S., Yu, R. and Wu, Y. (2017) Recent Progress on the Hydrogen Storage Properties of ZrCo-Based Alloys Applied in International Thermonuclear Experimental Reactor (ITER). Progress in Natural Science: Materials International, 27, 58-65. https://doi.org/10.1016/j.pnsc.2016.12.018

[2] Lin, H.J., Li, H.W., Shao, H., Lu, Y. and Asano, K. (2020) In Situ Measurement Technologies on Solid-State Hydrogen Storage Materials: A Review. Materials Today Energy, 17, Article ID: 100463. https://doi.org/10.1016/j.mtener.2020.100463

[3] Kojima, Y. (2019) Hydrogen Storage Materials for Hydrogen and Energy Carriers. International Journal of Hydrogen Energy, 44, 18179-18192. https://doi.org/10.1016/j.ijhydene.2019.05.119

[4] Rong, M., Wang, F., Wang, J., Wang, Z. and Zhou, H. (2017) Effect of Heat Treatment on Hydrogen Storage Properties and Thermal Stability of $\mathrm{V}_{68} \mathrm{Ti}_{20} \mathrm{Cr}_{12}$ Alloy. Progress in Natural Science: Materials International, 27, 543-549. https://doi.org/10.1016/j.pnsc.2017.08.012

[5] Rusman, N.A.A. and Dahari, M. (2016) A Review on the Current Progress of Metal Hydrides Material for Solid-State Hydrogen Storage Applications. International Journal of Hydrogen Energy, 41, 12108-12126. https://doi.org/10.1016/j.ijhydene.2016.05.244

[6] Sakintuna, B., Lamaridarkrim, F. and Hirscher, M. (2007) Metal Hydride Materials for Solid Hydrogen Storage: A review. International Journal of Hydrogen Energy, 32, 1121-1140. https://doi.org/10.1016/j.ijhydene.2006.11.022

[7] 2019) US DOE Funding Fuel Cell, Hydrogen Projects. Fuel Cells Bulletin, 2019, 13-14. https://doi.org/10.1016/S1464-2859(19)30391-8

[8] Tarasov, B.P., Fursikov, P.V., Volodin, A.A., Bocharnikov, M.S., Shimkus, Y.Y., Kashin, A.M., Yartys, V.A., Chidziva, S., Pasupathi, S. and Lototskyy, M.V. (2020) Metal Hydride Hydrogen Storage and Compression Systems for Energy Storage Technologies. International Journal of Hydrogen Energy. https://doi.org/10.1016/j.ijhydene.2020.07.085

[9] Boateng, E. and Chen, A. (2020) Recent Advances in Nanomaterial-Based Solid-State Hydrogen Storage. Materials Today Advances, 6, Article ID: 100022. https://doi.org/10.1016/j.mtadv.2019.100022

[10] Ren, J., Musyoka, N.M., Langmi, H.W., Mathe, M. and Liao, S. (2017) Current Research Trends and Perspectives on Materials-Based Hydrogen Storage Solutions: A Critical Review. International Journal of Hydrogen Energy, 42, 289-311. https://doi.org/10.1016/j.ijhydene.2016.11.195

[11] Pickering, L., Lototskyy, M.V., Wafeeq Davids, M., Sita, C. and Linkov, V. (2018) Induction Melted $\mathrm{AB}_{2}$-Type Metal Hydrides for Hydrogen Storage and Compression Applications. Materials Today: Proceedings, 5, 10470-10478. https://doi.org/10.1016/j.matpr.2017.12.378 
[12] Nei, J., Young, K., Salley, S.O. and Ng, K.Y.S. (2012) Effects of Annealing on $\mathrm{Zr}_{8} \mathrm{Ni}_{19} \mathrm{X}_{2}(\mathrm{X}=\mathrm{Ni}, \mathrm{Mg}, \mathrm{Al}, \mathrm{Sc}, \mathrm{V}, \mathrm{Mn}, \mathrm{Co}, \mathrm{Sn}, \mathrm{La}$, and Hf): Hydrogen Storage and Electrochemical Properties. International Journal of Hydrogen Energy, 37, 8418-8427. https://doi.org/10.1016/j.ijhydene.2012.02.066

[13] Kumar, S., Jain, A., Ichikawa, T., Kojima, Y. and Dey, G.K. (2017) Development of Vanadium Based Hydrogen Storage Material: A Review. Renewable and Sustainable Energy Reviews, 72, 791-800. https://doi.org/10.1016/j.rser.2017.01.063

[14] Guo, X., Wang, S., Liu, X., Li, Z., Lü, F., Mi, J., Hao, L. and Jiang, L. (2011) Laves Phase Hydrogen Storage Alloys for Super-High-Pressure Metal Hydride Hydrogen Compressors. Rare Metals, 30, 227-231. https://doi.org/10.1007/s12598-011-0373-7

[15] Zhang, Y., Wang, H., Zhai, T., Yang, T., Qi, Y. and Zhao, D. (2014) Hydrogen Storage Characteristics of the Nanocrystalline and Amorphous Mg-Nd-Ni-Cu-Based Alloys Prepared by Melt Spinning. International Journal of Hydrogen Energy, 39, 3790-3798. https://doi.org/10.1016/j.ijhydene.2013.12.139

[16] Lv, W., Shi, Y., Deng, W., Yuan, J., Yan, Y. and Wu, Y. (2016) Effect of Mg Substitution for La on Microstructure, Hydrogen Storage and Electrochemical Properties of $\mathrm{La}_{1-\mathrm{x}} \mathrm{Mg}_{\mathrm{x}} \mathrm{Ni}_{3.5}(\mathrm{x}=0.20,0.23,0.25$ at\%) Alloys. Progress in Natural Science: Materials International, 26, 177-181. https://doi.org/10.1016/j.pnsc.2016.03.008

[17] Huot, J. and Tousignant, M. (2017) Hydrogen Sorption Enhancement in Cold-Rolled

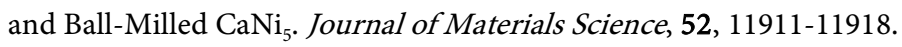
https://doi.org/10.1007/s10853-017-1250-Z

[18] Emami, H., Edalati, K., Matsuda, J., Akiba, E. and Horita, Z. (2015) Hydrogen Storage Performance of TiFe after Processing by Ball Milling. Acta Materialia, 88, 190-195. https://doi.org/10.1016/j.actamat.2014.12.052

[19] Chen, X.Y., Chen, R.R., Ding, X., Fang, H.Z., Guo, J.J., Ding, H.S., Su, Y.Q. and Fu, H.Z. (2018) Crystal Structure and Hydrogen Storage Properties of Ti-V-Mn Alloys. International Journal of Hydrogen Energy, 43, 6210-6218. https://doi.org/10.1016/j.ijhydene.2018.02.009

[20] Zhou, H.Y., Wang, F., Wang, J., Wang, Z.M., Yao, Q.R., Deng, J.Q., Tang, C.Y. and Rao, G.H. (2014) Hydrogen Storage Properties and Thermal Stability of $\mathrm{V}_{35} \mathrm{Ti}_{20} \mathrm{Cr}_{45}$ Alloy by Heat Treatment. International Journal of Hydrogen Energy, 39, 14887-14895. https://doi.org/10.1016/j.ijhydene.2014.07.054

[21] Shahi, R.R., Yadav, T.P., Shaz, M.A., Srivastava, O.N. and van Smaalen, S. (2011) Effect of Processing Parameter on Hydrogen Storage Characteristics of As Quenched $\mathrm{Ti}_{45} \mathrm{Zr}_{38} \mathrm{Ni}_{17}$ Quasicrystalline Alloys. International Journal of Hydrogen Energy, 36, 592-599. https://doi.org/10.1016/j.ijhydene.2010.10.031

[22] Hu, F., Wen, Y., Chan, K.C., Yue, T.M., Zhou, Y.Z., Zhu, S.L. and Yang, X.J. (2015) Synthesis of Self-Detached Nanoporous Titanium-Based Metal Oxide. Journal of Solid State Chemistry, 229, 78-86. https://doi.org/10.1016/j.jssc.2015.05.021

[23] Wang, W., Zhang, X. and Sun, J. (2018) Phase Stability and Tensile Behavior of Metastable $\beta$ Ti-V-Fe and Ti-V-Fe-Al Alloys. Materials Characterization, 142, 398-405. https://doi.org/10.1016/j.matchar.2018.06.008

[24] Itoh, H., Arashima, H., Kubo, K., Kabutomori, T. and Ohnishi, K. (2005) Improvement of Cyclic Durability of BCC Structured Ti-Cr-V Alloys. Journal of Alloys and Compounds, 404-406, 417-420. https://doi.org/10.1016/j.jallcom.2004.12.175

[25] Wang, X.Y., Zhang, S.L., Feng, S.D., Qi, L. and Liu, R.P. (2018) Effect of Pressure on the Structure of $\mathrm{Ti}_{75} \mathrm{Al}_{25}$ Alloy during Rapid-Quenching Process. Journal of Non-Crystalline Solids, 502, 136-141. https://doi.org/10.1016/j.jnoncrysol.2018.08.001

[26] Baster, D., Takasaki, A., Kuroda, C., Hanc, E., Lee, S.-H., Świerczek, K., Szmyd, J.S., 
Kim, J.-Y. and Molenda, J. (2013) Effect of Mechanical Milling on Electrochemical Properties of $\mathrm{Ti}_{45} \mathrm{Zr}_{38-\mathrm{x}} \mathrm{Ni}_{17+\mathrm{x}}(\mathrm{x}=0,8)$ Quasicrystals Produced by Rapid-Quenching. Journal of Alloys and Compounds, 580, S238-S242. https://doi.org/10.1016/j.jallcom.2013.03.272

[27] Liu, B., Zhang, Y., Mi, G., Zhang, Z. and Wang, L. (2009) Crystallographic and ElectroChemical Characteristics of Ti-Zr-Ni-Pd Quasicrystalline Alloys. International Journal of Hydrogen Energy, 34, 6925-6929.

https://doi.org/10.1016/j.ijhydene.2009.06.044

[28] Takasaki, A. and Kelton, K.F. (2002) High-Pressure Hydrogen Loading in $\mathrm{Ti}_{45} \mathrm{Zr}_{38} \mathrm{Ni}_{17}$ Amorphous and Quasicrystal Powders Synthesized by Mechanical Alloying. Journal of Alloys and Compounds, 347, 295-300. https://doi.org/10.1016/S0925-8388(02)00782-X

[29] Ouyang, L., Huang, J., Wang, H., Liu, J. and Zhu, M. (2017) Progress of Hydrogen Storage Alloys for Ni-MH Rechargeable Power Batteries in Electric Vehicles: A Review. Materials Chemistry and Physics, 200, 164-178. https://doi.org/10.1016/j.matchemphys.2017.07.002

[30] Liu, H., Zhai, X., Li, Z., Tao, X., Liu, W. and Zhao, J. (2018) Improved Electrochemical Hydrogen Storage Performance of $\mathrm{Ti}_{49} \mathrm{Zr}_{26} \mathrm{Ni}_{25}$ Quasicrystal Alloy by Doping with Mesoporous $\alpha-\mathrm{Fe}_{2} \mathrm{O}_{3}$ Particles. International Journal of Hydrogen Energy, 43, 7447-7455. https://doi.org/10.1016/j.ijhydene.2018.02.149

[31] Tian, F. and Li, N. (2020) Investigation of the Feasibility of A Novel Heat Stamping Process for Producing Complex-Shaped Ti-6Al-4V Panel Components. Procedia Manufacturing, 47, 1374-1380. https://doi.org/10.1016/j.promfg.2020.04.267

[32] Shukla, S. and Bajpai, V. (2020) Effect of Cryogenic Quenching on Microstructure and Microhardness of Ti-6Al-4V Alloy. Materials Letters, 267, Article ID: 127532. https://doi.org/10.1016/j.matlet.2020.127532

[33] Kumar, M., Xiong, X., Wan, Z., Sun, Y., Tsang, D.C.W., Gupta, J., Gao, B., Cao, X., Tang, J. and Ok, Y.S. (2020) Ball Milling as a Mechanochemical Technology for Fabrication of Novel Biochar Nanomaterials. Bioresource Technology, 312, Article ID: 123613. https://doi.org/10.1016/j.biortech.2020.123613

[34] Lee, J.-H., Park, H.-K., Kim, J.-H., Jang, J.-H., Hong, S.-K. and Oh, I.-H. (2020) Constitutive Behavior and Microstructural Evolution in Ti-Al-Si Ternary Alloys Processed by Mechanical Milling and Spark Plasma Sintering. Journal of Materials Research and Technology, 9, 2247-2258. https://doi.org/10.1016/j.jmrt.2019.12.056

[35] Khajavi, S., Rajabi, M. and Huot, J. (2019) Effect of Cold Rolling and Ball Milling on First Hydrogenation of $\mathrm{Ti}_{0.5} \mathrm{Zr}_{0.5}\left(\mathrm{Mn}_{1-\mathrm{x}} \mathrm{Fe}_{\mathrm{x}}\right) \mathrm{Cr}_{1}, \mathrm{x}=0$, 0.2, 0.4. Journal of Alloys and Compounds, 775, 912-920. https://doi.org/10.1016/j.jallcom.2018.10.179

[36] Das, B. and Patra, A. (2020) Fabrication of W-Ti-Mo Alloys and Its Microstructure, Mechanical Properties Prepared by Mechanical Alloying. Materials Today: Proceedings, 26, 2845-2852. https://doi.org/10.1016/j.matpr.2020.02.592

[37] Vega, L.E.R., Leiva, D.R., Leal Neto, R.M., Silva, W.B., Silva, R.A., Ishikawa, T.T., Kiminami, C.S. and Botta, W.J. (2020) Improved Ball Milling Method for the Synthesis of Nanocrystalline TiFe Compound Ready to Absorb Hydrogen. International Journal of Hydrogen Energy, 45, 2084-2093.

https://doi.org/10.1016/j.ijhydene.2019.11.035

[38] Ariga, Y., Takasaki, A., Kimijima, T. and Świerczek, K. (2015) Electrochemical Properties of $\mathrm{Ti}_{49} \mathrm{Zr}_{26} \mathrm{Ni}_{25-\mathrm{x}} \mathrm{Pd}_{\mathrm{x}}(\mathrm{x}=0-6)$ Quasicrystal Electrodes Produced by Mechanical Alloying. Journal of Alloys and Compounds, 645, S152-S154.

https://doi.org/10.1016/j.jallcom.2015.01.114 
[39] Sun, F., Yan, M.-Y., Liu, X.-P., Ye, J.-H., Li, Z.-N., Wang, S.-M. and Jiang, L.-J. (2015) Effect of $\mathrm{N}_{2}, \mathrm{CH}_{4}$ and $\mathrm{O}_{2}$ on Hydrogen Storage Performance of $2 \mathrm{LiNH}_{2}+$ $\mathrm{MgH}_{2}$ system. International Journal of Hydrogen Energy, 40, 6173-6179. https://doi.org/10.1016/j.ijhydene.2015.03.084

[40] Zhang, T.B., Yang, X.W., Li, J.S., Hu, R., Xue, X.Y. and Fu, H.Z. (2012) On the Poisoning Effect of $\mathrm{O}_{2}$ and $\mathrm{N}_{2}$ for the $\mathrm{Zr}_{0.9} \mathrm{Ti}_{0.1} \mathrm{~V}_{2}$ Hydrogen Storage Alloy. Journal of Power Sources, 202, 217-224. https://doi.org/10.1016/j.jpowsour.2011.12.002

[41] Sandrock, G. (1999) A Panoramic Overview of Hydrogen Storage Alloys from AGas Reaction Point of View. Journal of Alloys and Compounds, 293-295, 877-888. https://doi.org/10.1016/S0925-8388(99)00384-9

[42] Liu, H., Liu, W., Sun, Y., Chen, P., Zhao, J., Guo, X. and Su, Z. (2020) Preparation and Electrochemical Hydrogen Storage Properties of $\mathrm{Ti}_{49} \mathrm{Zr}_{26} \mathrm{Ni}_{25}$ Alloy Covered with Porous Polyaniline. International Journal of Hydrogen Energy, 45, 11675-11685. https://doi.org/10.1016/j.ijhydene.2020.02.115

[43] Lin, J., Sun, L., Cao, Z., Yin, D., Liang, F., Wu, Y. and Wang, L. (2016) A Novel Method to Prepare $\mathrm{Ti}_{1.4} \mathrm{~V}_{0.6} \mathrm{Ni}$ Alloy Covered with Carbon and Nanostructured $\mathrm{Co}_{3} \mathrm{O}_{4}$, and Its Good Electrochemical Hydrogen Storage Properties as Negative Electrode Material for Ni-MH battery. Electrochimica Acta, 222, 1716-1723. https://doi.org/10.1016/j.electacta.2016.11.163

[44] Zadorozhnyy, V., Klyamkin, S., Zadorozhnyy, M., Bermesheva, O. and Kaloshkin, S. (2012) Hydrogen Storage Nanocrystalline TiFe Intermetallic Compound: Synthesis by Mechanical Alloying and Compacting. International Journal of Hydrogen Energy, 37, 17131-17136. https://doi.org/10.1016/j.ijhydene.2012.08.078

[45] Abe, M. and Kuji, T. (2007) Hydrogen Absorption of TiFe Alloy Synthesized by Ball Milling and Post-Annealing. Journal of Alloys and Compounds, 446-447, 200-203. https://doi.org/10.1016/j.jallcom.2006.12.063

[46] Berdonosova, E.A., Klyamkin, S.N., Zadorozhnyy, V.Y., Zadorozhnyy, M.Y., Geodakian, K.V., Gorshenkov, M.V. and Kaloshkin, S.D. (2016) Calorimetric Study of Peculiar Hydrogenation Behavior of Nanocrystalline TiFe. Journal of Alloys and Compounds, 688, 1181-1185. https://doi.org/10.1016/j.jallcom.2016.07.145

[47] Hotta, H., Abe, M., Kuji, T. and Uchida, H. (2007) Synthesis of Ti-Fe Alloys by Mechanical Alloying. Journal of Alloys and Compounds, 439, 221-226. https://doi.org/10.1016/j.jallcom.2006.05.137

[48] Zaluski, L., Tessier, P., Ryan, D.H., Doner, C.B., Zaluska, A., Ström-Olsen, J.O., Trudeau, M.L. and Schulz, R. (1993) Amorphous and Nanocrystalline Fe-Ti Prepared by Ball Milling. Journal of Materials Research, 8, 3059-3068. https://doi.org/10.1557/JMR.1993.3059

[49] Falcão, R.B., Dammann, E.D.C.C., Rocha, C.J., Durazzo, M., Ichikawa, R.U., Martinez, L.G., Botta, W.J. and Leal Neto, R.M. (2018) An Alternative Route to Produce Easily Activated Nanocrystalline TiFe Powder. International Journal of Hydrogen Energy, 43, 16107-16116. https://doi.org/10.1016/j.ijhydene.2018.07.027

[50] Haraki, T., Oishi, K., Uchida, H., Miyamoto, Y., Abe, M., Kokaji, T. and Uchida, S. (2008) Properties of Hydrogen Absorption by Nano-Structured FeTi Alloys. International Journal of Materials Research, 99, 507-512. https://doi.org/10.3139/146.101669

[51] Vega, L.E.R., Leiva, D.R., Leal Neto, R.M., Silva, W.B., Silva, R.A., Ishikawa, T.T., Kiminami, C.S. and Botta, W.J. (2018) Mechanical Activation of TiFe for Hydrogen Storage by Cold Rolling under Inert Atmosphere. International Journal of Hydrogen Energy, 43, 2913-2918. https://doi.org/10.1016/j.ijhydene.2017.12.054 
[52] Edalati, K., Matsuda, J., Yanagida, A., Akiba, E. and Horita, Z. (2014) Activation of TiFe for Hydrogen Storage by Plastic Deformation Using Groove Rolling and High-Pressure Torsion: Similarities and Differences. International Journal of Hydrogen Energy, 39, 15589-15594. https://doi.org/10.1016/j.ijhydene.2014.07.124

[53] Manna, J., Tougas, B. and Huot, J. (2018) Mechanical Activation of Air Exposed $\mathrm{TiFe}+4 \mathrm{wt} \% \mathrm{Zr}$ Alloy for Hydrogenation by Cold Rolling and Ball Milling. International Journal of Hydrogen Energy, 43, 20795-20800.

https://doi.org/10.1016/j.ijhydene.2018.09.096

[54] Leng, H., Yan, P., Han, X., Liu, W., Liu, Q. and Li, Q. (2020) Microstructural Characterization and Hydrogenation Performance of $\mathrm{Zr}_{\mathrm{x}} \mathrm{V}_{5} \mathrm{Fe}(\mathrm{x}=3-9)$ Alloys. Progress in Natural Science: Materials International, 30, 229-238. https://doi.org/10.1016/j.pnsc.2020.01.002

[55] de Araujo-Silva, R.A., Jorge Jr., A.M., Vega, L.E.R., Leal Neto, R.M., Leiva, D.R. and Botta, W.J. (2019) Hydrogen Desorption/Absorption Properties of the Extensively Cold Rolled $\beta \mathrm{Ti}-40 \mathrm{Nb}$ Alloy. International Journal of Hydrogen Energy, 44, 20133-20144. https://doi.org/10.1016/j.ijhydene.2019.05.211

[56] Radhi, H.N., Aljassani, A.M.H. and Mohammed, M.T. (2020) Effect of ECAP on Microstructure, Mechanical and Tribological Properties of Aluminum and Brass Alloys: A Review. Materials Today: Proceedings, 26, 2302-2307. https://doi.org/10.1016/j.matpr.2020.02.497

[57] Polyakova, V.V., Semenova, I.P., Polyakov, A.V., Magomedova, D.K., Huang, Y. and Langdon, T.G. (2017) Influence of Grain Boundary Misorientations on the Mechanical Behavior of ANear- $\alpha$ Ti-6Al-7Nb Alloy Processed by ECAP. Materials Letters, 190, 256-259. https://doi.org/10.1016/j.matlet.2016.12.083

[58] Huang, S.-J., Chiu, C., Chou, T.-Y. and Rabkin, E. (2018) Effect of Equal Channel Angular Pressing (ECAP) on Hydrogen Storage Properties of Commercial Magnesium Alloy AZ61. International Journal of Hydrogen Energy, 43, 4371-4380. https://doi.org/10.1016/j.ijhydene.2018.01.044

[59] Bartha, K., Veverková, A., Stráský, J., Veselý, J., Minárik, P., Corrêa, C.A., Polyakova, V., Semenova, I. and Janeček, M. (2020) Effect of the Severe Plastic Deformation by ECAP on Microstructure and Phase Transformations in Ti-15Mo alloy. Materials Today Communications, 22, Article ID: 100811.

https://doi.org/10.1016/j.mtcomm.2019.100811

[60] Czerwinski, A., Lapovok, R., Tomus, D., Estrin, Y. and Vinogradov, A. (2011) The Influence of Temporary Hydrogenation on ECAP Formability and Low Cycle Fatigue Life of CP Titanium. Journal of Alloys and Compounds, 509, 2709-2715. https://doi.org/10.1016/j.jallcom.2010.11.188

[61] Verleysen, P. and Lanjewar, H. (2020) Dynamic High-Pressure Torsion: A Novel Technique for Dynamic Severe Plastic Deformation. Journal of Materials Processing Technology, 276, Article ID: 116393.

https://doi.org/10.1016/j.jmatprotec.2019.116393

[62] Zhilyaev, A.P. and Langdon, T.G. (2008) Using High-Pressure Torsion for Metal Processing: Fundamentals and Applications. Progress in Materials Science, 53, 893-979. https://doi.org/10.1016/j.pmatsci.2008.03.002

[63] Yang, J., Wang, G., Park, J.M. and Kim, H.S. (2019) Microstructural Behavior and Mechanical Properties of Nanocrystalline Ti-22Al-25Nb Alloy Processed by High-Pressure Torsion. Materials Characterization, 151, 129-136. https://doi.org/10.1016/j.matchar.2019.02.029

[64] Wei, D.-X., Koizumi, Y., Nagasako, M. and Chiba, A. (2017) Refinement of Lamel- 
lar Structures in Ti-Al Alloy. Acta Materialia, 125, 81-97.

https://doi.org/10.1016/j.actamat.2016.11.045

[65] Shuitcev, A., Gunderov, D.V., Sun, B., Li, L., Valiev, R.Z. and Tong, Y.X. (2020) Nanostructured $\mathrm{Ti}_{29.7} \mathrm{Ni}_{50.3} \mathrm{Hf}_{20}$ High Temperature Shape Memory Alloy Processed by High-Pressure Torsion. Journal of Materials Science \& Technology, 52, 218-225. https://doi.org/10.1016/j.jmst.2020.01.065

[66] Jia, J., Zhang, K. and Jiang, S. (2014) Microstructure and Mechanical Properties of Ti-22Al-25Nb Alloy Fabricated by Vacuum Hot Pressing Sintering. Materials Science and Engineering: A, 616, 93-98. https://doi.org/10.1016/j.msea.2014.08.018

[67] Niu, H.Z., Chen, Y.F., Zhang, D.L., Zhang, Y.S., Lu, J.W., Zhang, W. and Zhang, P.X. (2016) Fabrication of a Powder Metallurgy $\mathrm{Ti}_{2} \mathrm{AlNb}$-Based Alloy by Spark Plasma Sintering and Associated Microstructure Optimization. Materials \& Design, 89, 823-829. https://doi.org/10.1016/j.matdes.2015.10.042

[68] Lu, Z.-G., Wu, J., Guo, R.-P., Xu, L. and Yang, R. (2017) Hot Deformation Mechanism and Ring Rolling Behavior of Powder Metallurgy $\mathrm{Ti}_{2} \mathrm{AlNb}$ Intermetallics. Acta Metallurgica Sinica (English Letters), 30, 621-629.

https://doi.org/10.1007/s40195-017-0583-6

[69] Sim, K.H., Wang, G., Ju, J.M., Yang, J. and Li, X. (2017) Microstructure and Mechanical Properties of A Ti-22Al-25Nb Alloy Fabricated from Elemental Powders by Mechanical Alloying and Spark Plasma Sintering. Journal of Alloys and Compounds, 704, 425-433. https://doi.org/10.1016/j.jallcom.2017.01.354

[70] Shagiev, M.R., Galeyev, R.M., Valiakhmetov, O.R. and Safiullin, R.V. (2008) Improved Mechanical Properties of $\mathrm{Ti}_{2} \mathrm{AlNb}$-Based Intermetallic Alloys and Composites. Advanced Materials Research, 59, 105-108. https://doi.org/10.4028/www.scientific.net/AMR.59.105

[71] Mao, Y., Yang, S., Wu, C., Luo, L. and Chen, Y. (2017) Preparation of $\left(\mathrm{FeV}_{80}\right)_{48} \mathrm{Ti}_{26+\mathrm{x}} \mathrm{Cr}_{26}(\mathrm{x}=0-4)$ Alloys by the Hydride Sintering Method and Their Hydrogen Storage Performance. Journal of Alloys and Compounds, 705, 533-538. https://doi.org/10.1016/j.jallcom.2017.02.166

[72] El-Shafie, M., Kambara, S. and Hayakawa, Y. (2019) Hydrogen Production Technologies Overview. Journal of Power and Energy Engineering, 7, 107-154. https://doi.org/10.4236/jpee.2019.71007

[73] Rosen, M. (2015) The Prospects for Renewable Energy through Hydrogen Energy Systems. Journal of Power and Energy Engineering, 3, 373-377. https://doi.org/10.4236/jpee.2015.34050

[74] Ren, L., Zhou, S. and Ou, X. (2020) Life-Cycle Energy Consumption and Greenhouse-Gas Emissions of Hydrogen Supply Chains for Fuel-Cell Vehicles in China. Energy, 209, 118482. https://doi.org/10.1016/j.energy.2020.118482

[75] Thomas, J.M., Edwards, P.P., Dobson, P.J. and Owen, G.P. (2020) Decarbonising Energy: The Developing International Activity in Hydrogen Technologies and Fuel Cells. Journal of Energy Chemistry, 51, 405-415. https://doi.org/10.1016/j.jechem.2020.03.087 